\title{
Physical Education, Sports and Health Teacher Performance in Primary Schools of Padang
}

\author{
*Fitri Lavenia \\ Faculty of Sport Science \\ Universitas Negeri Padang \\ Padang, Indonesia \\ fitrilavenia991@gmail.com
}

\author{
Edwarsyah \\ Faculty of Sport Science \\ Universitas Negeri Padang \\ Padang, Indonesia
}

\begin{abstract}
The study was based on field observations at the start with the aim to find out about the performance of teachers of physical education and Sports Health State elementary schools-city of Padang Pauh Subdistrict. The type of this research is descriptive research with quantitative methods, namely regarding planning, implementation, and evaluation of learning in physical education sport and health in elementary school. The population of this research is the teachers of physical education, sports, and health in elementary school that registered in the 2017/2018 school year, implementing the KTSP totaling 15 people. The sampling technique was purposive sampling. Data obtained using a Likert scale score that is: always (S), Often (SR), sometimes (KD), never (TP). Data analysis was done by counting the frequency and percentage of answers. The results showed that the performance of the teacher of physical education, sports, and health belong in the category of less and better. Performance-based of teachers in planning factor in both categories of $80.10 \%$. Performance-based of teachers in implementation factors in categories of $34.56 \%$. Teacher Performance Evaluation factors based on learning in the category of $75.83 \%$.
\end{abstract}

Keywords- Physical Education, Teacher Performance, Sports and Health

\section{INTRODUCTION}

In the learning process, a task to be executed is a teacher, plan, implement and evaluate learning learning [1]. Planning made by teachers must be in accordance with the concept of education and learning contained in the curriculum.Strategic planning is a thought about what is being implemented in learning so as to create a system that allows the occurrence of a learning process and can bring students to achieve the expected goals. Further evaluation is carried out to measure the degree of achievement of the purpose and effectiveness of the learning process is implemented. Evaluation is the process that is the basis of feedback to improve the learning system. In order for the evaluation activities to achieve maximum results should the evaluation must be conducted continuously.

Based on the observations of the author conducted several public elementary schools in the district of Padang Pauh that learning penjasorkes dengaan not run properly, so the level pencapaiaan learning outcomes are not yet fully reached the limit of the expected category. Due to the lack of the ability of teachers in lesson planning, the lack of ability of teachers to implementation learning, the lack of ability of teachers to evaluate learning, facilities and infrastructure and less precise methods of teaching used by teachers. Based on the description above, the writer wanted to know about the teacher's performance penjasorkes in making lesson planning, implementing and evaluating instructional teaching physical education and sport in accordance with the expected health curriculum.

Physical education is a form of education that is structured in a systematic and targeted through physical activity which includes the elements of cognitive, affective, and psychomotor in order to improve the whole person [2].

Thus, teachers determine the quality of education, the success of the learning process, implementation or otherwise of interest and learning, terorganisasikannya infrastructure, students, media, tools and learning resources. Performance good teachers can create learning effectiveness and efficiency of sera can establish the discipline of students, schools and teachers themselves.

The performance of the teacher is a teacher's ability to carry out the task of teaching in schools and is responsible for the students under his guidance to improve the performance of learners [3]

Factors that affect a person's work performance or the performance include the environment, behavior management, office design, performance assessment, feedback and wage administration [3].

Unit Level Curriculum (KTSP) is operational curriculum developed by and implemented in each educational unit [4]. The KTSP is an idea of the curriculum development placed in a position closest to the school learning and education units [1]. The KTSP is the operational curriculum developed and implemented by each educational unit [4].

Curriculum 2013 is a curriculum that simplify, thematic, increase school hours and aims to encourage learners or students to be able to better observation, questioning, reasoning, and communicate what they earn or they know after receiving learning materials and students are expected to have competence attitudes, skills and knowledge are much better.

\section{RESEARCH METHOD}

This type of research is descriptive research with quantitative methods taking into account that this study reveals social phenomena and lifted the facts fairly, not a state controlled and manipulated.

This research was conducted at the State Elementary School (SDN) se Padang Pauh subdistrict in January 2018. 
The population in this study were teachers in public elementary school penjasorkes sub-district of Padang Pauh. And sampling of the writer take public elementary school is still wearing the curriculum SBC 2006, thus the number of schools 15 and 15 respondents.

In this study, the instruments used to collect data was a questionnaire or a questionnaire. The tools used to obtain the data in this study is in the form of questionnaires or by questionnaires were given to sports and physical education teachers in public primary school health sub-district of Padang Pauh.

Data analysis techniques used to analyze a questionnaire distributed to teachers of physical education and health statistics were used sports percentage. Analysis of the data used is Descriptive Analysis Techniques percentage calculations can be calculated using the formula:

$$
\mathrm{P}=\mathrm{x} 100
$$

\section{RESULT AND DISCUSSION}

\section{Lesson Planning}

In the aspect of the performance of teachers of Physical Education, Sport and Health related lesson plans achieving an ideal score in 1020 of a total score of 817 . That is, the planning of teaching in elementary schools throughout the District Padang Pauh reached $80.10 \%$ in both categories.

Indicators learning plan with the level of achievement of $74.02 \%$ and lesson planning indicator criteria are the criteria. When viewed statement answered the respondents to the criteria of Always (S) amounted to $40.39 \%$, Frequent (SR) amounted to $27.84 \%$, Sometimes (KD) of 19:22\% and criteria Never (TP) 12:55\%.

\section{Learning Implementation}

In the aspect of the performance of teachers of Physical Education, Sport and Health on the implementation of the overall learning achieving an ideal score of 2700 out of a total score of 933. That is, the implementation of the State Primary School learning sub-district of Padang Pauh reached $34.56 \%$ in the category of Less well.

\section{Evaluation of learning}

In the aspect of the performance of teachers of Physical Education, Sport and Health-related evaluation of learning achieving an ideal score of 480 out of a total score of 364. That is, the evaluation of learning in the District Elementary School se Padang Pauh reached 75.83 in both categories.

\section{Discussion}

a. Teacher Lesson Planning by State Primary School Penjasorkes se Padang Pauh Subdistrict

Planning is an integral part of effective learning. The learning process premeditated will appear more clear and focused. For that kemempuan teachers in making learning plan is needed to remind their teaching skills.

To find out more about lesson planning researchers asked questions as many as 17 items. The study's findings about lesson planning by teachers of physical education and sports in the State Primary
School health sub-district of Padang Pauh as a whole is in good category $(80.10 \%)$

Based on the data processed lesson planning by teachers of Physical Education and Health at the State Elementary School Padang Pauh Subdistrict se are in either category. Then in the preparation of physical education teacher lesson planning exercise and health at State Elementary School throughout Padang Pauh Kecamtan penjasorkes teachers have been able to in the preparation of planning in accordance with the principles of lesson planning and preparation of lesson planning procedures.

b. Teacher Learning Implementation by State Primary School Penjasorkes sub-district of Padang Pauh

Learning implementation pokonya consists of three activities, namely: classroom management, use of learning strategies and the use of media. The weakness of the teachers are seen in the use of learning strategies and media, while the class considered good management, especially senior teachers and have the attitude and character discipline.

According to data collected from the 20 items represents indicators of the implementation of the statement of learning by teachers overall Penjasorkes are in the unfavorable category $(34.56 \%)$. To improve the implementation of learning and achievement of learning goals Penjasorkes a teacher should be guided by the RPP.

A teacher penjasorkes should be able to make the students active in learning and also motivate the students so that the students can be actively involved every activity. "For one teacher motivation or spur aims to mobilize the student to arise willingness and desire to improve their academic achievement in order to reach the goal of education of students with what was expected and adequate for the school curriculum" [5]. The award can be social, position, promotions and praise.

c. Evaluation of Learning by Teachers Penjasorkes se Elementary School in the District Pauh Padang

Evaluation of the plan as an attempt to determine how far the program objectives was achieved. Therefore, evaluation of physical education related to the understanding of the formulation of the objectives of physical education.

Evaluation serves as a way to monitor the progress of learning and knowing how far the teaching objectives can be achieved by students. From the evaluation of learning has seen teachers do their job properly, because the format of the raw ratings set by the government, teachers also have some ability to assess the ability of a learner.

According to data collected from 8 statement items represent indicators of learning evaluation by teachers penjasorkes are in good classification (75.83\%). Then in the evaluation of teachers teaching Physical Education and Health at the State Elementary School se Padang Pauh Subdistrict teachers have been guided in assessment techniques. 
The results of this study will ultimately determine how far the purpose of education and teaching that has been achieved.

\section{CONCLUSION}

From the research that has been conducted to determine the performance of teachers in the learning penjasorkes in primary schools throughout the District Pauh Padang in the learning process, it can be concluded as follows: 1) Master Penjasorkes sub-district Pauh Padang in the learning plan have good criteria with percentages $80.10 \%$, 2) Master Penjasorkes sub-district of Padang Pauh in the implementation of learning criteria less well with the percentage of $34.56 \%, 3$ ) Master Penjasorkes sub-district of Padang Pauh in a good learning evaluation criteria with a percentage of $75.83 \%$

According to the conclusion it is recommended: 1) for researchers, to increase knowledge and adds greater insight into the performance of which must be implemented by teachers penjasorkes and in accordance with the demands of the curriculum, 2) for teachers, teachers are expected to prepare for the implementation of learning better. So as to achieve the goal of learning is maximized, 3) for educational institutions, educational institutions are expected this thesis can be used as additives reading in the library that can be developed by the parties to broaden the reader to increase knowledge about the performance of physical education teachers and sports health , 4) for further research, to further research is expected to be able to do research on teacher performance penjasorkes with different methods and designs.

\section{REFERENCES}

[1] E. Mulyasa. "Menjadi Guru Profesional: Menciptakan Pembelajaran Kreatif dan Menyenangkan”. Bandung: Remaja Rosdakarya. 2005, pp. 25.

[2] G. Wiarto. "Inovasi Pembelajaran dalam Pendidikan Jasmani”. Yogyakarta: Laksitas. 2015, pp. 37.

[3] Supardi. "Kinerja Guru (Edisi Revisi III)". Jakarta: Rajawali Press. 2016, pp. 56.

[4] Badan Standar Nasional Pendidikan (BNSP), Panduan Penyusunan Kurikulum Tingkat Satuan Pendidikan Jenjang Pendidikan Dasar dan Menengah. Jakarta. 2006, pp. 25.

[5] N. Purwanto. "Belajar Berhubungan Dengan Perubahan Tingkah Laku”. Jakarta: PT Rineka Cipta. 1990, pp. 67. 